\section{Concept and evaluation of food craving: unidimensional scales based on the Trait and the State Food Craving Questionnaire}

\author{
O conceito e a avaliação da compulsão alimentar: \\ escalas unidimensionais baseadas no Trait e no \\ State Food Craving Questionnaire
}

Mara Fernandes Maranhão 1

Nara Mendes Estella 1

Hugo Cogo-Moreira 1

Ulrike Schmidt 2

Iain C. Campbell 2

Angélica Medeiros Claudino 1

doi: 10.1590/0102-311X00144717

\begin{abstract}
"Craving" is a motivational state that promotes an intense desire related to consummatory behaviors. Despite growing interest in the concept of food craving, there is a lack of available instruments to assess it in Brazilian Portuguese. The objectives were to translate and adapt the Trait and the State Food Craving Questionnaire (FCQ-T and FCQ-S) to Brazilian Portuguese and to evaluate the psychometric properties of these versions.The FCQ-T and FCQ-S were translated and adapted to Brazilian Portuguese and administered to students at the Federal University of São Paulo. Both questionnaires in their original models were examined considering different estimators (frequentist and bayesian). The goodness of fit underlying the items from both scales was assessed through the following fit indices: $\chi^{2}$, WRMR residual, comparative fit index, Tucker-Lewis index and RMSEA. Data from 314 participants were included in the analyses. Poor fit indices were obtained for both of the original questionnaires regardless of the estimator used and original structural model. Thus, three eating disorder experts reviewed the content of the instruments and selected the items which were considered to assess the core aspects of the craving construct. The new and reduced models (questionnaires) generated good fit indices. Our abbreviated versions of FCQ-S and FCQ-T considerably diverge from the conceptual framework of the original questionnaires. Based on the results of this study, we propose a possible alternative, i.e., to assess craving for food as a unidimensional construct.
\end{abstract}

Craving; Binge-Eating Disorder; Obesity; Questionnaires
Correspondence

M. F. Maranhão

Universidade Federal de São Paulo.

Rua Borges Lagoa 570, São Paulo, SP 04038-000, Brasil. mara.proata@gmail.com

1 Universidade Federal de São Paulo, São Paulo, Brasil.

2 King's College London, London, U.K. 


\section{Introduction}

Craving is a common phenomenon. Prevalence rates of food craving in college students have been reported to be as high as $97 \%$ of women and $68 \%$ of men 1 . Food craving is associated with increased food consumption in restrained eaters 2 , is positively correlated with body mass index 3,4 , and often leads to weight gain and obesity. It has also been associated with failure to complete weight-loss treatments 5 and with the potential to trigger purging behaviors 6 . Even in non-clinical populations, food cravings may evoke strong feelings of ambivalence and guilt 2,3 . However, definitions of food craving are heterogeneous, and there is a lack of well-established measures. Self-report questionnaires have been used to measure food craving, but the constructs being assessed by these questionnaires are complex. Further studies are needed to examine and measure its complexities, as this may be a potentially modifiable determinant of energy intake and nutritional quality.

"Craving" designates a motivational state that promotes an intense desire related to consummatory or ingestive behaviors 1,7,8. Craving is also an important aspect of substance abuse and addiction, and has been used to study altered eating behavior 9,10. Craving is a complex phenomenon, and cross-cultural aspects may aggravate investigating it. For instance, issues related to the definition and understanding of "craving", and how these terms are translated and/or may be altered by translation 11 should always be considered.

The term "craving" is derived from the Old Icelandic or Norse word "krefja", which means "to beg" or "to demand" 8,12. In the addiction field, "craving" has been described as "urgent desire, longing, [or] yearning" 8 (p. 459) or "intensely wanting" 1. Many definitions of food and drug cravings are linguistically similar, but conceptualization of craving is more problematic in the context of "food", as food comprises many macro and micronutrients and is not addictive in its true sense 13.

The controversial conceptual status of craving may reflect the lack of a comprehensive etiological model that distinguishes the core components of food craving (e.g. urgent or intense desire to eat; recurrent thoughts or preoccupation with craved food) from aspects that may be involved during craving experiences (e.g. hunger, loss of control over eating). Importantly, experiencing craving does not necessarily lead to food intake. Also, food ingestion occurs despite craving. Likewise, hunger is not a precondition for craving. Cravings that lead to episodes of binge eating, for example, are more likely to happen in the context of diminished hunger but increased negative affect 6,13.

In addition, the notion of craving appears to be strongly culture-bound 14. For example, sweet cravings (which are prominent in Western cultures) - are virtually absent in other countries. For example, in a study conducted by Parker et al. 11, only 1\% of young Egyptian men and 6\% of young Egyptian women reported cravings for chocolate. Likewise, they were also far more likely to crave for savory foods than sweet foods. This indicates that attitudes towards food and eating may play a critical role in the experience of food cravings.

Despite the challenges in understanding and measuring food cravings, studies have been developed that explore the links between craving for food and binge eating 15 , menstrual cycle 16, depression 17, obesity, and eating disorders 9,10. Different instruments have been used, such as the Food Cravings Questionnaire (FCQ, including a State and a Trait versions 18,19), the Attitudes to Chocolate Questionnaire (ACQ 20), the Orientation Towards Chocolate Questionnaire (OCQ 21), the Food Craving Inventory (FCI 22) and the Questionnaire on Craving for Sweet or Rich Foods (QCSRF 23). These instruments assess habitual cravings related to specific kinds of foods and explore certain dimensions of food cravings. The FCQ, however, was constructed to assess cravings for a variety of foods. The FCQ combines two versions that measure current (state) and habitual (trait) food cravings, and is a well-established instrument that has been translated and adapted to Spanish 18, Dutch 3, German 24 and Korean 25. The psychometric properties of the FCQs have been tested on healthy subjects 18,19 and on eating disorders clinical samples 26,27 , and considered to be satisfactory by researchers. The conceptual framework by CepedaBenito et al. 18 recognizes food craving as a multifaceted (multidimensional) construct that embraces cognitive, physiological, and behavioral aspects.

The aims of this study were to translate and adapt the FCQ (Trait and State) to Brazilian Portuguese, and to administer it to a sample of Brazilian university students in order to verify the factorial validity of the Brazilian Portuguese translated versions. Based on the findings, a subsequent aim was set: to develop a new and concise instrument to measure food craving. 


\section{Method}

\section{Instruments: the Trait and the State Food Craving Questionnaire}

The FCQ-T has 39 items that investigate nine factors by asking individuals to indicate, for each item, how often each statement is, in general, true, by using a six-point scale (answers ranging from "never or not applicable" to "always"). The FCQ-T includes the following factors: (i) intention and plan of consuming food (e.g. "Food cravings invariably make me think of ways to get what I want to eat"), (ii) anticipation of positive reinforcement that may result from eating (e.g. "Eating what I crave makes me feel better"), (iii) anticipation of relief from negative states and feelings as a result of eating (e.g. "When I satisfy a craving, I feel less depressed"), (iv) possible lack of control over eating if food is eaten (e.g. "If I eat what I am craving, I often lose control and eat too much"), (v) thoughts or preoccupation with food (e.g. "If I am craving something, thoughts of eating it consume me"), (vi) craving as a physiological state (e.g. "I crave foods when my stomach is empty"), (vii) emotions that may be experienced before or during food craving or eating (e.g. "My emotions often make me want to eat"), (viii) environmental cues that may trigger food cravings (e.g. "Being with someone who is eating often makes me hungry"), (ix) guilt that may be experienced as a result of craving and/or giving into them (e.g. "When I eat what I am craving, I feel guilty about myself").

The FCQ-S has 15 items and five factors. Individuals are asked to indicate the extent to which they agree with each of the statements at the "specific moment", by using a five-point Likert scale ranging from "strongly agree" to "strongly disagree". The FCQ-S factors are: (i) an intense desire to eat (e.g. "I have an urge for one or more specific foods"), (ii) anticipation of positive reinforcement that may result from eating (e.g. "Eating one or more specific foods would make things seem just perfect"), (iii) anticipation of relief from negative states and feelings as a result of eating (e.g. "Satisfying my craving would make me feel less grouchy and irritable"), (iv) lack of control over eating (e.g. "If I have one or more specific foods, I cannot stop eating it"), and (v) craving as a physiological state (e.g. "I am hungry").

The original English versions of the questionnaires were examined for goodness of fit in previous research, and a 97\% fit for the FCQ-T and 94\% fit for the FCQ-S were reported 18 . As fit indices, the authors examined: the $\chi^{2}$ statistic, the goodness-of-fit index (GFI), the normed-fit index (NFI), the Tucker-Lewis index (TLI), the comparative fit index (CFI), and the Root Mean Square Error or Approximation (RMSEA).

\section{Translation and adaptation to Brazilian Portuguese of the FCQ-S and FCQ-T}

Two native Brazilian Portuguese speakers independently translated the original English versions of the questionnaires. This was intended to minimize errors and diverging interpretations of terms and expressions. The two translators then met to identify and discuss differences found between the two versions. A version based on the consensual combination of the two translated versions was prepared and later revised by an expert and researcher in the eating disorder field: this resulted in the first Brazilian Portuguese version of the questionnaires. Another translator, unaware of the original instrument and fluent in Portuguese and English, back-translated the questionnaires to English. The back-translated versions of the FCQ-T and the FCQ-S were then reviewed by a committee (translators and eating disorders researchers) and sent to the author of the original questionnaires for approval.

To maximize the attainment of semantic, idiomatic and conceptual equivalence between the original English version and the first Brazilian Portuguese version, the questionnaires were distributed to ten individuals (university professors) who provided detailed feedback, which was then incorporated into a second Brazilian Portuguese version of the questionnaires. Subsequently, this second version of the questionnaires was used on a group of seventeen individuals (mental health professionals with experience in the eating disorders field) who were also asked to provide comments, suggestions and raise any doubts on unclear items or concerns, in order to further improve the translated instruments. These observations were also taken into consideration by the investigators, and minor changes were made to the questionnaires, resulting in the third and final Brazilian Portuguese version of the FCQ-S 
and FCQ-T, which was translated to Portuguese as: "Questionário sobre Desejo Intenso por Comida Estado" (QDIC-E) and "Questionário sobre Desejo Intenso por Comida - Traço" (QDIC-T).

\section{Sample and procedures}

The translated and adapted original versions of the FCQ-S and FCQ-T were applied to a convenience sample of undergraduate and graduate students from the Federal University of São Paulo (UNIFESP), Brazil, who voluntarily agreed to take part in the study. Participants were students enrolled in the fall semester of 2014 who were at least 18 years old, agreed with the procedures and aims of the study and signed the informed consent. They anonymously completed the Brazilian Portuguese version of the FCQs and a short form indicating their sex, age, ethnicity, height, weight, whether they had ever been diagnosed with any eating disorder and if yes, when. They also indicated the time at which they had last eaten. Financial compensation was not provided to participants. The Research Committee Review Board at UNIFESP approved the study and all participants gave their written informed consent.

\section{Statistical analysis}

The two questionnaires (FCQ-T and FCQ-S) adapted to Brazilian-Portuguese were evaluated regarding their dimensional structure using, as measurement model, the well-fitted solution obtained by Cepeda-Benito et al. 18 where the FCQ-S has five factors and the FCQ-T has nine factors. Both scales were examined under a confirmatory factor analysis (CFA), in which, when the items (i.e., the observed variables) are categorical, it is also referred to as item response theory (IRT) analysis 28,29 . As conducted in previous studies 30,31 , three different estimators were used: (a) weighted least square mean and variance-adjusted $\chi^{2}$ test (WLSMV), (b) maximum likelihood 30, and (c) generalized least squares (GLS) 31. Under such estimators, the goodness of fit underlying the items from both questionnaires was assessed through the following fit indices: $\chi^{2}$, weighted root mean square residual (WRMR) 32 , CFI 33 , TLI 34 and RMSEA. The following cut-off criteria were used to determine a good model fit: $\chi^{2}$ not statistically significant $(>0.05)$, WRMR near or below 0.95 , an RMSEA near or below 0.06 , and CFI and TLI near or above 0.95 . An overall conclusion about the fit of each model was obtained by considering these indices simultaneously 35,36. All the above-cited estimators are based on frequentist statistical approach. We also used a Bayes estimator, which is a more flexible approach in the context of confirmatory factor analysis, allowing informative priors specification for the cross-loading by using means of zero and normal distribution with small variance 0.02 37. In the context of frequentist (traditional) confirmatory factor analysis, zero cross-loadings are specified for the factor indicators that are hypothesized as not being influenced by certain factors. Under such conceptualization of how a multidimensional confirmatory factor model is specified, such an exact zero loading might be viewed as a prior distribution that has mean zero and variance zero ${ }^{37}$. Under the bayesian context, a prior that probably more accurately reflects substantive theory uses a mean of zero and a normal distribution with small variance, where a factor loading is denoted by $\lambda \sim \mathrm{N}(0,0.01)$, and $95 \%$ of the loading variation is between -0.2 and +0.2 . Considering the standardized version of the factor loadings, values around 0.2 are considered a small loading, implying that cross-loading is close to zero, but not exactly zero.

Model estimation was performed with a default of 10,000 iterations for the two measurement models, with approximate zero residual correlations using the Markov Chain Monte Carlo algorithm, with unperturbed starting value information, and the Gibbs sampler 37,38.

Bayesian confirmatory factor analysis model fit was assessed with posterior predictive p-value and bayesian posterior predictive checking (PPC) using the likelihood-ratio $\chi^{2}$ statistic 39 ; Muthén 40 describes that PPC is evaluated for the data at the Bayes-estimated parameter values. It is compared to a distribution of such values obtained by many replications of the sequence: (1) drawing Bayes parameter estimates from the posterior distribution; (2) drawing a sample of synthetic observations on the 12 outcomes given the parameter values obtained in (1); and (3) computing the likelihood-ratio $\chi^{2}$ statistic for this synthetic sample 37 . While a low posterior predictive $\mathrm{p}$-value $(<0.05)$ and positive 95\% lower limit point to a poor model did fit, a well-fitting model is expected to show a posterior predictive p-value around 0.5 and a symmetric $95 \%$ confidence interval $(95 \% \mathrm{CI})$ for the difference 
between the observed and the replicated $\chi^{2}$ values for the bayesian centering on zero. All statistical analyses were carried out in MPlus 7.2 (Muthén \& Muthén, Los Angeles, USA).

In view of the poor fit indices obtained from different analytical approaches, as a post-hoc procedure, a group of three experts specialized in eating disorders, in a consensus meeting, was invited to propose a reduced version of the scales including items that were considered by them to assess core aspects of food craving. The group of experts was called, regardless of it being a non-clinical sample, because it was fundamental to select the items based on the phenomenology of eating disorders, which is a specific area of Psychiatry, demanding specific knowledge on the field of eating behavior and its psychopathological aspects.

\section{Results}

Three hundred and thirty-one students participated in the study. Seventeen were excluded due to a previous or current diagnosis of eating disorders (self-reported). A total of 314 scores from the questionnaires were used in the analysis. Participants were $77.1 \%$ females $(\mathrm{n}=242)$ and $22.9 \%$ males $(\mathrm{n}=72)$. The mean age was 22.5 years, and mean body mass index (BMI) was $24 \mathrm{~kg} / \mathrm{m}^{2}$.

The fit indices' models for both versions of the "original" (adapted to Brazilian Portuguese) FCQ under different estimators are reported (Table 1). As described, regardless of the adopted estimator, for the FCQ-S, the fit indices returned as a poor fit. In the FCQ-T case, problems in the convergence were raised, because the latent variable covariate matrix (psi) (i.e., correlation between the latent variables) was not positive definite. Therefore, the specified model for FCQ-T, when applied to the Brazilian sample, is inadmissible statistically, being necessary to re-specify the measurement model.

Due to poor overall fit indices observed using both approaches (frequentist and bayesian), for both the state and trait original questionnaires, three experts in the eating disorders field were invited to review the items of the questionnaires separately. These professionals were instructed to exam which of the items best captured the craving construct. A statistician then joined the discussion to refine the construct by considering only the items that were identified by the three experts to best assess the core aspects of the craving experience. This resulted in merging similar items, reducing complexity and redundancies of the original models (questionnaires), and were then considered for reanalysis. The new models (questionnaires) recommended by the experts understood the craving concept as a unidimensional construct, which generated good fit indices (Table 1).

Small adjustments based on theoretical assumptions were conducted via modification indices, where residual correlation among pairs of items were added for both models, resulting in good fit indices. In the case of the FCQ-S, one residual correlation between items 12 and 11 (items related to obsessive preoccupation with food) was found; for the FCQ-T, three residual correlations were identified as follows: item 27 with item 8 (items involving self-consciousness of the preoccupation or presence of thoughts related to eating), item 32 with item 33 (items involving ruminative thoughts of eating), and item 36 with item 25 (items involving lack of control over eating).

These modifications lead to the development of a new and shorter modified Brazilian Portuguese versions of the FCQs. The 8-item modified version of FCQ-T included the following statements obtained from the original version's sub-scales: 1 . thoughts or preoccupation with food (4 items); 2 . having intentions and plans to consume food ( 1 item); 3. emotions that may be experienced before or during food cravings or eating ( 1 item); 4 . cues that may trigger food cravings ( 1 item) and; 5 . lack of control over eating ( 1 item) (Table 2$)$.

The 5-item modified version of FCQ-S included the following statements obtained from the original version's sub-scales: 1 . intense desire to eat (3 items) and; 2 . lack of control over eating ( 2 items) (Table 3). Table 2 and Table 3 show the items of the modified versions of FCQ-T and FCQ-S and their corresponding original item numbers and subscales 18,19 .

The shorter Brazilian Portuguese models of the FCQ-T and FCQ-S considered the items as ordinal (as originally proposed, i.e., Likert scale), so the robust WLSMV was used for the parameters estimation, except for the latent factors where the numbers presented stand for variance and mean, respectively. The diagrams of the Brazilian-Portuguese models and standardized factor loadings (and standard error in parenthesis) are shown in Figures 1 and 2. 
Table 1

Fit indices' models for the original and reviewed versions of the State and Trait Food Craving Questionnaires (FCQ-S and FCQ-T).

\begin{tabular}{|c|c|c|c|c|c|c|c|c|c|c|c|}
\hline & $\begin{array}{l}\text { Questionnaire } \\
\text { and number of items }\end{array}$ & Estimator & $\chi^{2}$ & $\chi^{2} \mathrm{DF}$ & $\begin{array}{c}\chi^{2} \\
\text { p-value }\end{array}$ & RMSEA & $\begin{array}{l}\text { RMSEA } \\
(90 \% \mathrm{Cl})\end{array}$ & CFI & TLI & SRMR & WRMR \\
\hline Original & FCQ-S (15 items) & WLSMV & 399,625 & 80 & $<0.001$ & 0.11 & $\begin{array}{c}0.099- \\
0.121\end{array}$ & 0.957 & 0.944 & * & 1.195 \\
\hline Original & FCQ-S (15 items) & $\begin{array}{l}\text { ML (under } \\
\text { continuous } \\
\text { variables) }\end{array}$ & 284,992 & 80 & $<0.001$ & 0.088 & $\begin{array}{l}0.077- \\
0.099\end{array}$ & 0.927 & 0.904 & 0.06 & * \\
\hline Original & FCQ-S (15 items) & GLS & 185,922 & 80 & $<0.001$ & 0.063 & $\begin{array}{c}0.051- \\
0.075\end{array}$ & 0.745 & 0.665 & 0.076 & * \\
\hline Original & FCQ-T (39 items) & WLSMV & ** & ** & ** & ** & $\star *$ & ** & ** & * & ** \\
\hline Original & FCQ-T (39 items) & $\mathrm{ML}$ & ** & $* *$ & ** & ** & $* *$ & $\star *$ & $* *$ & ** & * \\
\hline Original & FCQ-T (39 items) & GLS & ** & ** & ** & $* *$ & $* *$ & $* *$ & $* *$ & ** & * \\
\hline Reviewed & FCQ-S (5 items) & WLSMV & 5,638 & 4 & 0.2279 & 0.035 & $\begin{array}{c}0.000- \\
0.096\end{array}$ & 1.000 & 0.999 & * & 0.251 \\
\hline Reviewed & $\begin{array}{c}\text { FCQ-S (5 items) } \\
\text { without modified } \\
\text { indices }\end{array}$ & WLSMV & 94,829 & 5 & $<0.001$ & 0.233 & $\begin{array}{l}0.193- \\
0.275\end{array}$ & 0.973 & 0.946 & & 1.229 \\
\hline Reviewed & FCQ-T (8 items) & WLSMV & 22,807 & 17 & 0.1556 & 0.032 & $\begin{array}{l}0.000- \\
0.063\end{array}$ & 0.998 & 0.996 & * & 0.37 \\
\hline Reviewed & $\begin{array}{c}\text { FCQ-T (8 items) } \\
\text { without modified } \\
\text { indices }\end{array}$ & WLSMV & 60,435 & 20 & $<0.001$ & 0.078 & $\begin{array}{l}0.056- \\
0.101\end{array}$ & 0.985 & 0.979 & & 0.638 \\
\hline
\end{tabular}

90\%Cl: 90\% confidence interval; CFI: comparative fit index; DF: dregrees of freedom; GLS: generalized least squares; ML: maximum likelihood; RMSEA: root mean square error of approximation; SRMR: standardized root mean square residual; TLI: Tucker-Lewis index; WLSMV: weighted least square mean and variance; WRMR: weighted root mean square residual.

* Not available for this estimator;

** Latent variable covariance matrix (psi) is not positive definite.

Figures 3 and 4 show the information curve for the estimated latent trait. Information curves evaluate the precision of the latent measurement throughout different amounts of traits, showing that the highest information provided by both tests are around 1.6 for the latent trait and 1.0 for the latent state.

\section{Discussion}

The present study was primarily conducted to verify the factorial validity of the Brazilian Portuguese versions of the FCQ Trait and State. Due to poor fit indices observed with frequentist and Bayesian approaches to the originally adapted versions of these questionnaires, short versions of the two questionnaires were developed which included only the items considered to assess the core construct of craving. The unidimensional model, with a one-factor structure, showed satisfactory fit with our sample data. In this context, the term unidimensional is defined as items that measure the same construct".

In comparison to the original questionnaires 18 , the currently proposed short version of the FCQ-T does not include items of the sub-scales "guilt", "craving as hunger", "anticipation of positive reinforcement from eating" and "anticipation of relief from negative states and feelings from eating". Likewise, the proposed short version of FCQ-S does not include items of the sub-scales "craving as hunger", "anticipation of positive reinforcement from eating" and "anticipation of relief from negative 
Table 2

Modified Trait Food Craving Questionnaires (FCQ-T) with 8 items.

\begin{tabular}{|c|c|c|}
\hline Item & Original item number & Original subscale \\
\hline $\begin{array}{l}\text { O desejo difícil de controlar por comida sempre me faz pensar em maneiras } \\
\text { de conseguir aquilo que eu quero comer } \\
\text { (Food cravings invariably make me think of ways to get what I } \\
\text { want to eat) }\end{array}$ & 5 & $\begin{array}{l}\text { Having intentions and plans to } \\
\text { consume food }\end{array}$ \\
\hline $\begin{array}{l}\text { Eu me pego preocupado(a) com comida } \\
\text { (I find myself preoccupied with food) }\end{array}$ & 8 & Thoughts or preoccupation with food \\
\hline $\begin{array}{l}\text { Eu não tenho força de vontade para resistir ao meu desejo difícil de } \\
\text { controlar por comida } \\
\text { (I have no will power to resist my food crave) }\end{array}$ & 25 & Lack of control over eating \\
\hline $\begin{array}{l}\text { Eu não consigo parar de pensar em comer, por mais que eu tente } \\
\text { (I can't stop thinking about eating no matter how hard I try) }\end{array}$ & 27 & Thoughts or preoccupation with food \\
\hline $\begin{array}{l}\text { Quando estou estressado(a) eu sinto um desejo difícil de controlar por } \\
\text { comida } \\
\text { (When I'm stressed out, I crave food) }\end{array}$ & 30 & Thoughts or preoccupation with food \\
\hline $\begin{array}{l}\text { Toda vez que eu sinto um desejo difícil de controlar por comida, eu fico } \\
\text { pensando nisso até de fato conseguir comer } \\
\text { (Whenever I have a food craving, I keep on thinking about eating until I } \\
\text { actually eat the food) }\end{array}$ & 32 & Thoughts or preoccupation with food \\
\hline $\begin{array}{l}\text { Se eu estou com um desejo difícil de controlar por comida, os pensamentos } \\
\text { de comer me consomem } \\
\text { (If I am craving something, thoughts of eating it consume me) }\end{array}$ & 33 & $\begin{array}{l}\text { Emotions that may be experienced } \\
\text { before or during food cravings or } \\
\text { eating }\end{array}$ \\
\hline $\begin{array}{l}\text { Para mim, é difícil resistir à tentação de comer alimentos apetitosos que } \\
\text { estão ao meu alcance } \\
\text { (It is hard for me to resist the temptation to eat appetizing foods that } \\
\text { are within reach) }\end{array}$ & 36 & Cues that may trigger food cravings \\
\hline
\end{tabular}

states and feelings from eating”. These new proposed abbreviated versions of the state and trait FCQs diverge considerably from the concepts of the original questionnaires. It is possible that part of the lack of fit using both frequentist and bayesian statistical approaches may be due to a non-parsimonious models' structure a priori. Even when the more flexible bayesian approach was used 37 , the tested models returned poor fit indices.

Despite being the most extensively validated instrument to measure cravings for food 4,18,19,25, the factorial structure of the FCQ original versions could be only partially replicated in the German 41 and Dutch 25 studies, both of which showed that the FCQ had good psychometric properties, though with fewer number of factors. In addition, another study 42 aimed to develop and validate a short version of the FCQ-T (FCQ-T-r) that included 15 items with the highest item-total-correlations selected from the original 39-item questionnaire 18. The authors conducted two studies to examine reliability and validity of this reduced form of the FCQ-T. Factor structure was tested in study 1 ( $\mathrm{N}=323$ students), which was an online questionnaire-based study. In study 2, a different sample of female students $(\mathrm{N}=70)$ performed a working memory task involving food and neutral pictures. Study 1 showed that the FCQ-T-r had a one-factorial structure and high internal consistency. Women and current dieters had higher FCQ-T-r scores, replicating findings from studies using the long version 31 . In study 2, again, the FCQ-T-r had high internal consistency, and positive correlations were found with attentional impulsivity, restrained eating, and eating disorder psychopathology. The unidimensionality of the FCQ-T-r (Spanish version) was then tested and confirmed in a subsequent study involving two independent samples of non-clinical Cuban adults (Sample 1: N = 368; Sample 2: $N=246$ ). CFA were conducted to simultaneously test model fit statistics and dimensionality of the instrument 30 . 
Table 3

Modified State Food Craving Questionnaires (FCQ-S) with 5 items.

Item

(I have an intense desire to eat one or more specific foods)

Estou com um desejo difícil de controlar (por um ou mais alimentos específicos)

(I'm craving one or more specific foods)

Eu estou sentindo uma necessidade urgente (de um ou mais alimentos específicos)

(I have an urge for one or more specific foods)

Meu desejo de comer (um ou mais alimentos específicos) parece irresistível

(My desire to eat [one or more specific foods] seems overpowering)

Eu sei que vou continuar pensando sobre (um ou mais alimentos específicos) até que eu consiga

obtê-los

(I know I'm going to keep on thinking about one or more specific foods until I actually have it)

Original item

number

1

2

3

11

12
Original subscale

Intense desire to eat

Intense desire to eat

Intense desire to eat

Lack of control over eating

Lack of control over

eating

\section{Figure 1}

Trait diagram.

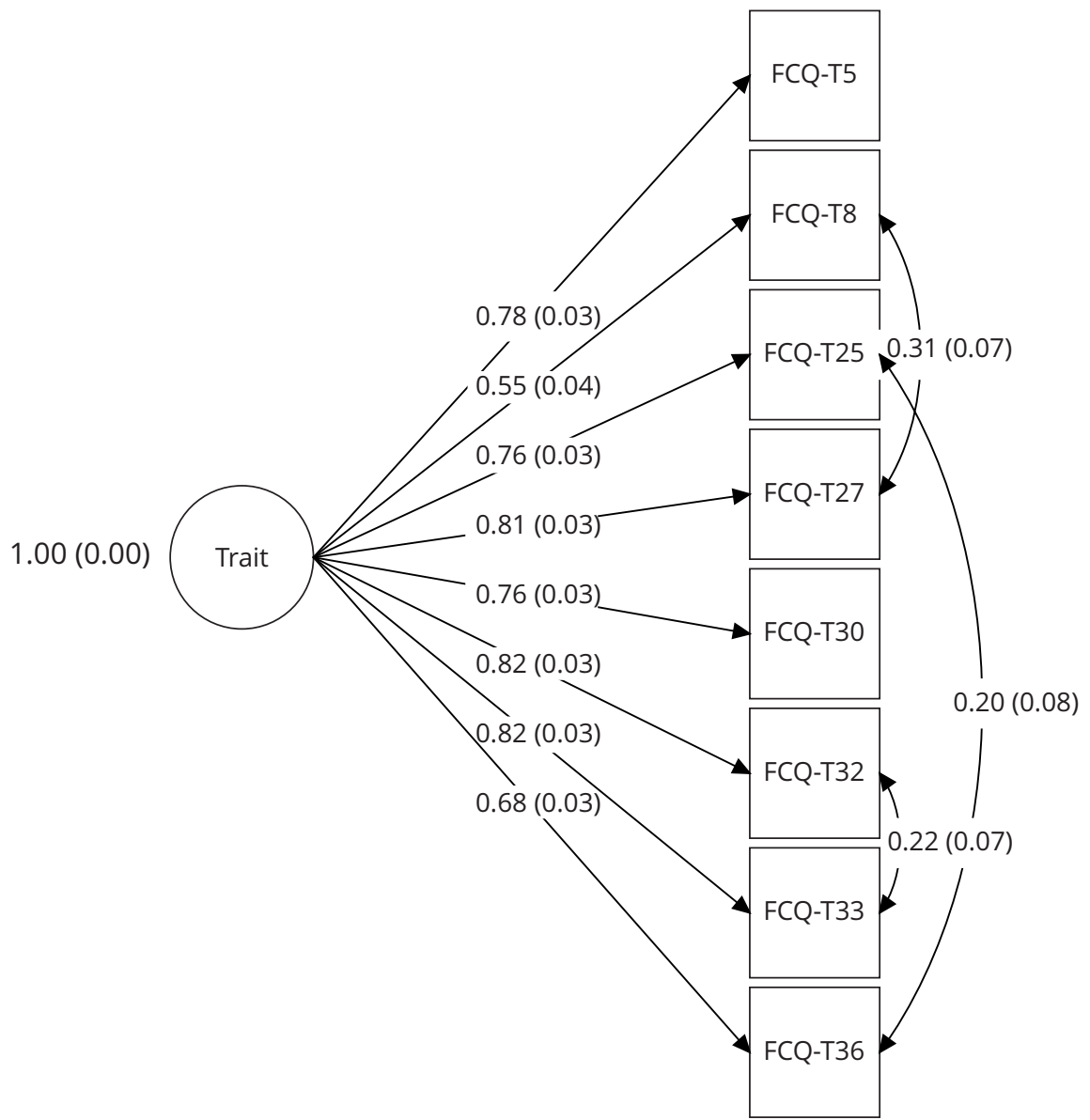




\section{Figure 2}

State diagram.

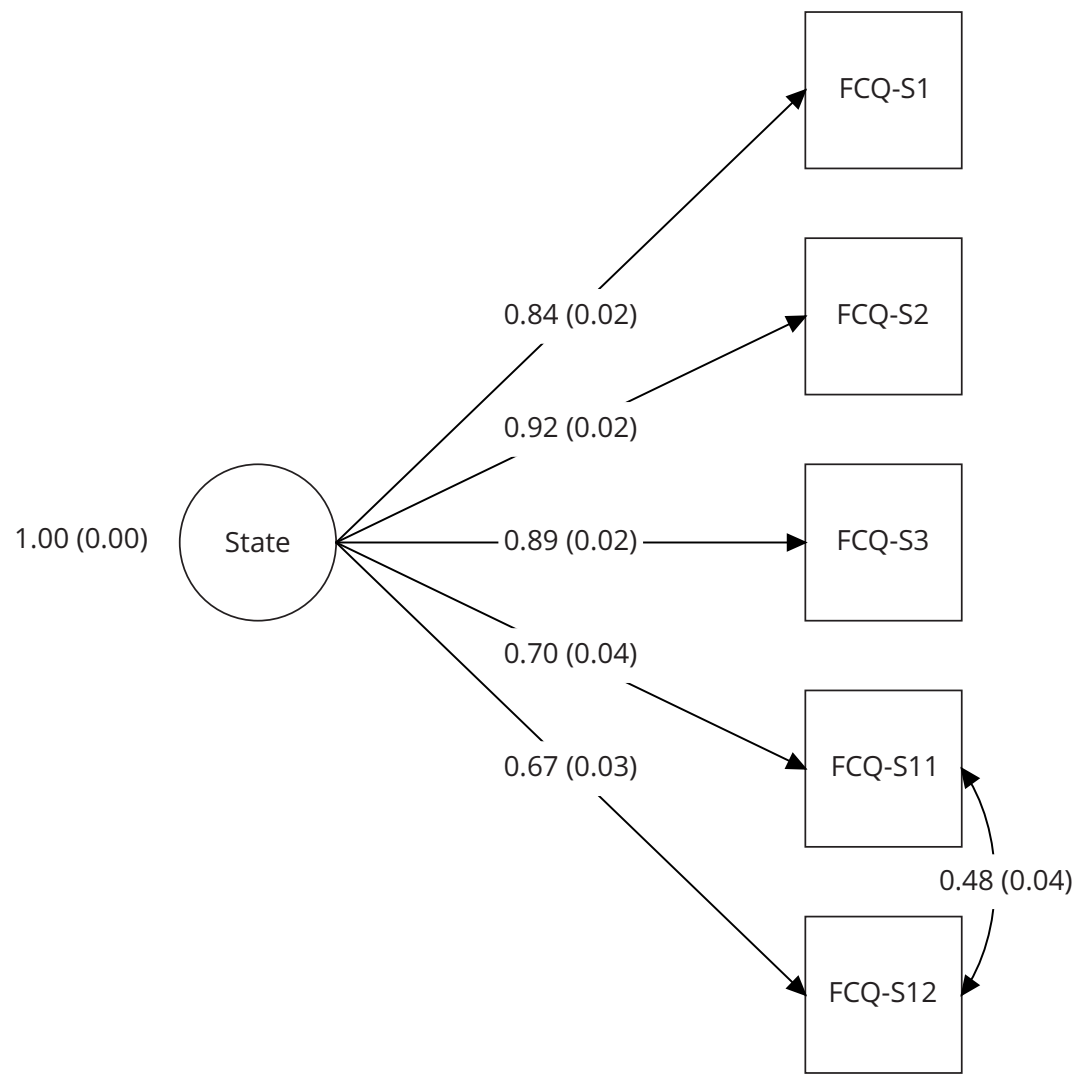

A different study 43 also used CFA to verify the psychometric properties of the FCQ-T-r (Italian version) in a cross-validation study. Again, the model that assumed the presence of a single latent variable showed an acceptable fit to the data. Recently, a group of Brazilian researchers translated and adapted the original FCQ-T and FCQ-S questionnaires to Brazilian Portuguese 44 and used intraclass correlation for semantic equivalence analysis, with satisfactory results. However, these questionnaires' versions were not tested in a sample that allow the evaluation of the questionnaires psychometric properties, such as the construct validity conducted by our group.

In line with previous research 30,42,43, the proposed unidimensional model for the trait and the state short versions of FCQs included the behavioral and cognitively affectively charged aspects of craving (Tables 2 and 3). Although there is no consensus on the definition of food craving, the intensity and specificity of the desire, as well as the ambivalence toward the aimed food, seem to constitute core components of the craving phenomenon 13,42. The previously proposed Elaborated Intrusion Theory of Desire (EI theory) 45 , which was further explored in the context of appetitive behaviors and food intake 46 , may offer a framework to understand how motivational context can affect the conscious experience of craving. According to EI theory, the key process underpinning craving episodes is the progressive elaboration of target-related thoughts, initially recognized as "intrusive" in nature. In other words, an intense desire for a particular food may be pleasurable when immediate access is 
Figure 3

Trait information curve.

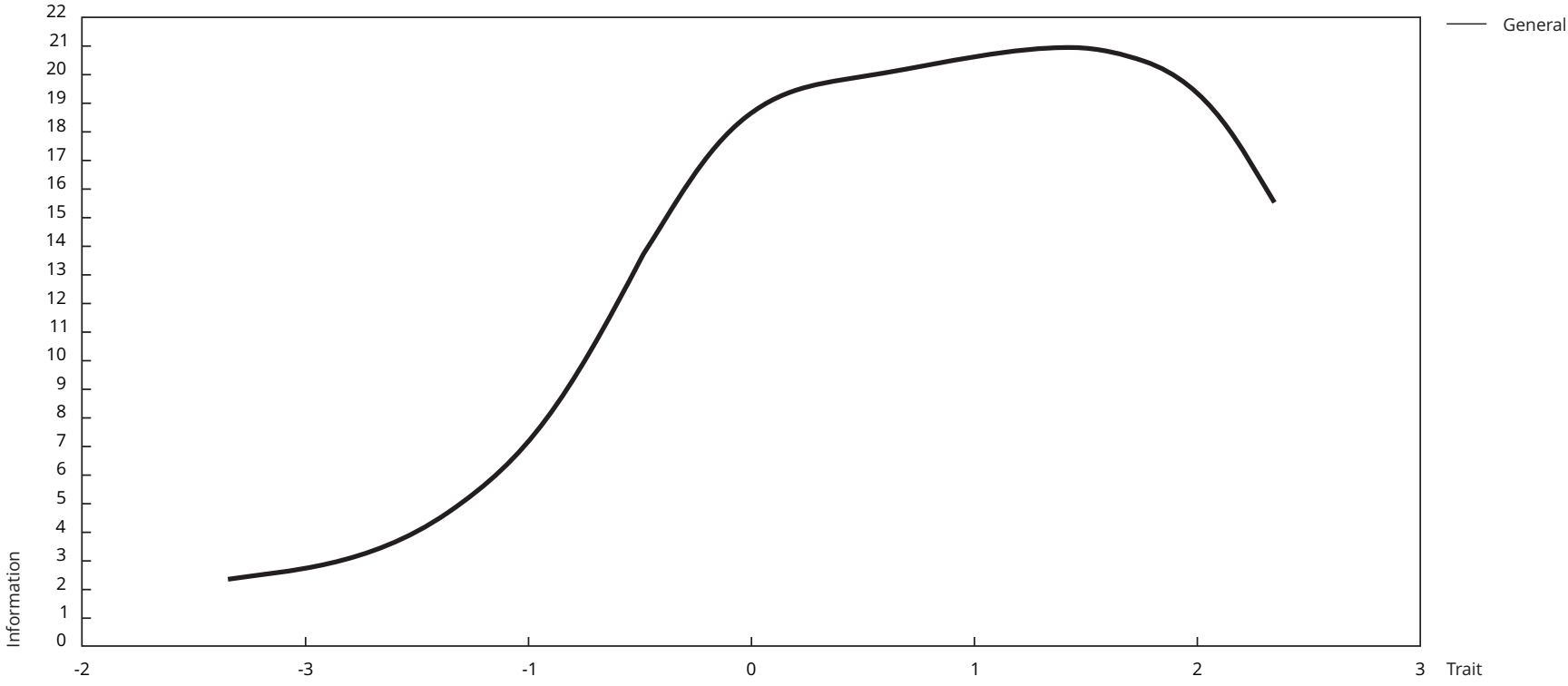

Figure 4

State information curve.

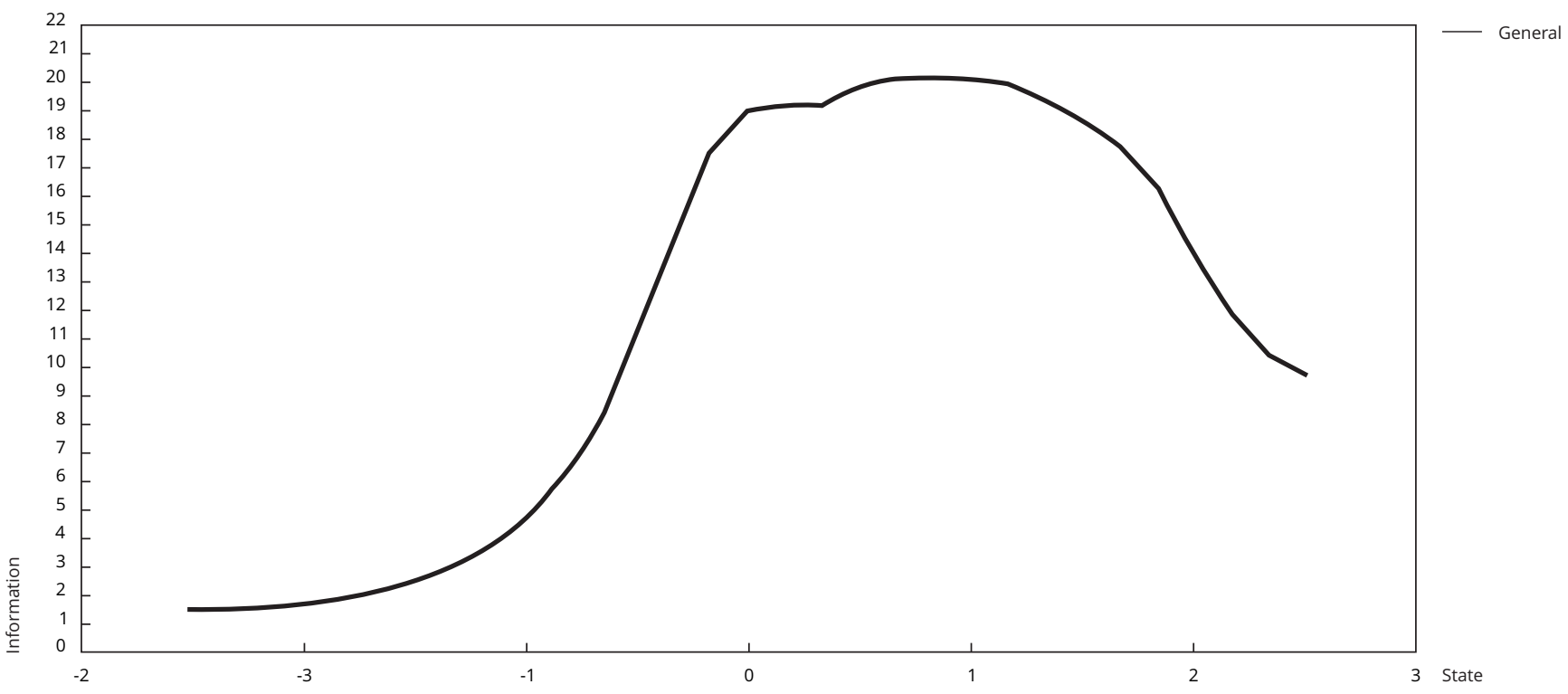


possible and when there are no immediate concerns about negative consequences of consumption. However, craving can be experienced as particularly aversive when consumption is not possible or in the context of attempted control. In this case, motivational conflict towards approaching and avoiding two competing goals (e.g., eating chocolate or sticking to one's diet), gives rise to the fear of losing control 45,47 .

This study proposes an alternative way of assessing cravings for food, which should be seen as a unidimensional construct on a continuum of experience ranging from mild to extreme. After being tested in studies that conduct exploratory factor analysis, we expect that this reduced version of the FCQ can be considered for use in investigating the food craving phenomenon in Brazilian samples, where this research field is limited by the unavailability of instruments developed for this aim. Although our brief versions of FCQ-T (8 items) and FCQ-S (5 items) included statements from different conceptual craving categories, as defined by the original author 18 , those items refer mainly to the core unidimensional craving construct, grouped as the affectively charged and goal-oriented character of the craving phenomenon. It may at the same time have the advantage of excluding: aspects which are difficult to report (such as habitual experiences of hunger), or aspects that may only be epiphenomenal to the craving phenomenon. Another important aspect that can be considered as a strength of the proposed brief scales in this study is that they potentially improve the applicability of the original and longer scales, especially in studies that involve repeated assessments using multiple questionnaires, where the application of brief scales is less tiresome.

Despite the strengths of this study, there are some limitations to our conclusions. It should be noted that this study provides the translation and adaptation of the FCQs, the study of the factorial analysis of the original Brazilian Portuguese translated version of the FCQ (State and Trait) and its modified short versions. Future studies should conduct an analysis of the psychometric properties of the Brazilian short versions of FCQs, particularly in groups of individuals with obesity and eating disorders. In addition, the study participants are considered to be from a convenience sample because they were students in the university where the study was being conducted. Extending the evaluation of the questionnaires to other ages and sociodemographic groups seems crucial. For instance, the validation of the Brazilian Portuguese version of the FCQs in children and adolescents would be of interest, as they represent groups in which interventions focused on the prevention of food craving, binge eating and consequent weight gain are lacking. In addition, invariance testing for different groups (i.e., age, sex) will provide future insights about how meaningfully the scales are comparable.

\section{Contributors}

M. F. Maranhão contributed to conceptualization of the paper, interpretation and manuscript preparation. N. M. Estella contributed to data collection, data entry, conceptualization of the paper, data interpretation and manuscript preparation. H. Cogo-Moreira contributed to data analyses, interpretation and revision of final manuscript. U. Schmidt contributed to interpretation and revision of final manuscript. I. C. Campbell contributed to data interpretation and revision of final manuscript. A. M. Claudino contributed to conceptualization of the paper, interpretation, manuscript preparation and final revision.

\section{Acknowledgments}

This work was supported by the São Paulo State Research Foundation (FAPESP; 2014/04258-5) and the Brazilian National Research Council (CNPq; 448058/2014-6). N. M. Estella and M. F. Maranhão received doctoral scholarships from the Brazilian Graduate Studies Coordination Board (Capes). We thank Prof. Cepeda-Benito for authorizing the translation and revising the back-translation of the FCQs. We thank Prof. João F. Marcolan for the contribution with recruitment. 


\section{References}

1. Weingarten HP, Elston D. The phenomenology of food cravings. Appetite 1990; 15:231-46.

2. Fedoroff IC, Polivy J, Herman CP. The effect of pre-exposure to food cues on the eating behavior of restrained and unrestrained eaters. Appetite 1997; 28:33-47.

3. Franken IH, Muris P. Individual differences in reward sensitivity are related to food craving and relative body weight in healthy women. Appetite 2005; 45:198-201.

4. Nijs IM, Franken IH, Muris P. The modified Trait and State Food-Cravings Questionnaires: development and validation of a general index of food craving. Appetite 2007; 49:38-46.

5. Sitton SC. Role of craving for carbohydrates upon completion of a protein-sparing fast. Psychol Rep 1991; 69:683-6.

6. Waters A, Hill A, Waller G. Internal and external antecedents of binge eating episodes in a group of women with bulimia nervosa. Int $\mathrm{J}$ Eat Disord 2001; 29:17-22.

7. Baker TB, Morse E, Sherman JE. The motivation to use drugs: a psychobiological analysis of urges. Nebr Symp Motiv 1986; 34:257-323.

8. Hormes JM, Rozin P. Does "craving" carve nature at the joints? Absence of a synonym for craving in many languages. Addict Behav 2010; 35:459-63.

9. Campbell H, Oscar-Berman M, Giordano J, Beley T, Barh D, Downs B, et al. Common phenotype in patients with both food and substance dependence: case reports. J Genet Syndr Gene Ther 2013; 4:pii.1000122.

10. Rogers PJ, Smit HJ. Food craving and food "addiction": a critical review of the evidence from a biopsychosocial perspective. Pharmacol Biochem Behav 2000; 66:3-14.

11. Parker S, Kamel N, Zellner D. Food craving patterns in Egypt: comparisons with North America and Spain. Appetite 2003; 40:193-5.

12. The American heritage dictionary of the English Language. Boston: Houghton Mifflin Company; 2000.

13. Hill AJ. The psychology of food craving. Proc Nutr Soc 2007; 66:277-85.

14. Hormes JM. Towards a socio-cultural model of food cravings [Master's Thesis]. Philadelphia: University of Pennsylvania; 2010.

15. Van den Eynde F, Claudino AM, Mogg A, Horrell L, Stahl D, Ribeiro W, et al. Repetitive transcranial magnetic stimulation reduces cue-induced food craving in bulimic disorders. Biol Psychiatry 2010; 67:793-5.
16. Dye L, Warner P, Bancroft J. Food craving during the menstrual cycle and its relationship to stress, happiness of relationship and depression; a preliminary enquiry. J Affect Disord 1995; 34:157-64.

17. Bancroft J, Williamson L, Warner P, Rennie D, Smith SK. Perimenstrual complaints in women complaining of PMS, menorrhagia, and dysmenorrhea: toward a dismantling of the premenstrual syndrome. Psychosom Med 1993; 55:133-45.

18. Cepeda-Benito A, Gleaves DH, Fernandez MC, Vila J, Williams TL, Reynoso J. The development and validation of Spanish versions of the State and Trait Food Cravings Questionnaires. Behav Res Ther 2000; 38:1125-38.

19. Cepeda-Benito A, Ferrer AR. Smoking Consequences Questionnaire-Spanish. Psychol Addict Behav 2000; 14:219-30.

20. Benton D, Greenfield K, Morgan M. The development of the Attitudes to Chocolate Questionnaire. Pers Individ Dif 1998; 24:513-20.

21. Cartwright F, Stritzke WG. A multidimensional ambivalence model of chocolate craving: construct validity and associations with chocolate consumption and disordered eating. Eat Behav 2008; 9:1-12.

22. White MA, Whisenhunt BL, Williamson DA, Greenway FL, Netemeyer RG. Development and validation of the food-craving inventory. Obes Res 2002; 10:107-14

23. Toll BA, Katulak NA, Williams-Piehota P, O'Malley S. Validation of a scale for the assessment of food cravings among smokers. Appetite 2008; 50:25-32.

24. Meule A, Westenhofer J, Kubler A. Food cravings mediate the relationship between rigid, but not flexible control of eating behavior and dieting success. Appetite 2011; 57:582-4.

25. Noh J, Kim JH, Nam H, Lim M, Lee D, Hong K. Validation of the Korean version of the General Food Cravings Questionnaire-Trait (G-FCQT). Korean J Clin Psychol 2008; 27:1039-51.

26. Moreno S, Rodríguez S, Fernandez MC, Tamez J, Cepeda-Benito A. Clinical validation of the trait and state versions of the Food Craving Questionnaire. Assessment 2008; 15:375-87.

27. Vander Wal JS, Johnston KA, Dhurandhar NV. Psychometric properties of the State and Trait Food Cravings Questionnaires among overweight and obese persons. Eat Behav 2007; 8:211-23. 
28. Fox J-P. Bayesian item response modeling: theory and applications. New York: Springer; 2010.

29. van der Linden WJ, Hambleton RK. Handbook of modern item response theory. New York: Springer; 2013.

30. Rodríguez-Martín BC, Molerio-Pérez O. Exploring the factor structure of the Food Cravings Questionnaire-Trait in Cuban adults. Front Psychol 2014; 5:214.

31. Cepeda-Benito A, Fernandez MC, Moreno S. Relationship of gender and eating disorder symptoms to reported cravings for food: construct validation of state and trait craving questionnaires in Spanish. Appetite 2003; 40:47-54.

32. Muthén LK, Muthén BO. MPlus user's guide. 6th Ed. Los Angeles: Muthén \& Muthén; 1998.

33. Bentler PM. Comparative fit indexes in structural models. Psychol Bull 1990; 107:238-46.

34. Tucker LR, Lewis G. The reliability coefficient for maximum likehood factor analysis. Psychometrika 1973; 38:197-201.

35. Hu L-T, Bentler PM. Cutoff criteria for fit indexes in covariance structure analysis: conventional criteria versus new alternatives. Struct Equ Modeling 1999; 6:1-55.

36. Yu C-Y. Evaluating cutoff criteria of model fit indices for latent variable models with binary and continuous outcomes. Los Angeles: University of California; 2002.

37. Muthén BO, Asparouhov T. Bayesian structural equation modeling: a more flexible representation of substantive theory. Psychol Methods 2012; 17:313-35.

38. Song X-Y, Lee S-Y. Basic and advanced bayesian structural equation modeling. Chichester: John Wiley \& Sons; 2012.

39. Asparouhov T, Muthén B. Bayesian analysis using MPlus: technical implementation. https://www.statmodel.com/download/ Bayes3.pdf (accessed on 18/Feb/2015).
40. Muthén B. Bayesian analysis in MPlus: a brief introduction. http://www.statmodel.com/ download/IntroBayesVersion (accessed on 18/ Feb/2015).

41. Meule A, Lutz A, Vogele C, Kubler A. Food cravings discriminate differentially between successful and unsuccessful dieters and nondieters. Validation of the Food Cravings Questionnaires in German. Appetite 2012; 58:8897.

42. Meule A, von Rezori V, Blechert J. Food addiction and bulimia nervosa. Eur Eat Disord Rev 2014; 22:331-7.

43. Iani L, Barbaranelli C, Lombardo C. Cross-validation of the reduced form of the Food Craving Questionnaire-Trait using confirmatory factor analysis. Front Psychol 2015; 6:433.

44. Ulian M. Cross-cultural adaptation of the State and Trait Food Cravings Questionnaires (FCQ-S and FCQ-T) into Portuguese. Ciênc Saúde Coletiva 2017; 22:403-16.

45. Kavanagh DJ, Andrade J, May J. Imaginary relish and exquisite torture: the elaborated intrusion theory of desire. Psychol Rev 2005; 112:446-67.

46. Cunningham TJ, Barradas DT, Rosenberg KD, May AL, Kroelinger CD, Ahluwalia IB. Is maternal food security a predictor of food and drink intake among toddlers in Oregon? Matern Child Health J 2012; 16 Suppl 2:339-46.

47. Aldao A, Wisco B. Motivational conflict influences the timing of emotions and their regulation. Motiv Emot 2015; 39:943-52. 


\section{Resumo}

A compulsão alimentar ("craving" ou "fissura") é um estado motivacional que produz um desejo intenso relacionado a comportamentos de consumo. Apesar do crescente interesse no conceito da compulsão alimentar, para poder avaliá-la adequadamente, faltam instrumentos traduzidos e adaptados para o português do brasileiro. Os objetivos foram traduzir e adaptar o Trait e o State Food Craving Questionnaire (FCQ-T e FCQ-S) para o português brasileiro e avaliar as propriedades psicométricas destas versões. O FCQ-T e FCQ-S foram traduzidos e adaptados para ao português brasileiro e aplicados a alunos da Universidade Federal de São Paulo. Os modelos originais de ambos os questionários foram analisados com diferentes estimadores (de frequência e bayesianos). Foi avaliada a qualidade do ajuste subjacente aos itens de ambas escalas, usando os seguintes indices: $\chi^{2}$, $W R M R$, indice de ajuste comparativo, indice de Tucker-Lewis e RMSEA. As análises incluíram os dados de 314 participantes. Foram obtidos indices de ajuste baixos para ambos questionários originais, independentemente do estimador utilizado e do modelo estrutural original. Assim, três especialistas em transtornos alimentares revisaram o conteúdo dos instrumentos e selecionaram os itens para avaliar os aspectos centrais do construto de compulsão alimentar. Os modelos (questionários) novos e reduzidos produziram índices satisfatórios de qualidade de ajuste. Discussão: Nossas versões abreviadas do FCQ-S e do FCQ-T divergem consideravelmente do arcabouço conceitual dos questionários originais. Com base nos achados, propomos uma alternativa possivel, isto é, para avaliar a compulsão alimentar enquanto construto unidimensional.

Fissura; Transtorno da Compulsão Alimentar; Obesidade; Questionários

\section{Resumen}

"Craving" es un estado motivacional que suscita un deseo intenso relacionado con hábitos de consumo. A pesar del creciente interés en el concepto de food craving (antojos alimentarios), existe una falta de disponibilidad de instrumentos para evaluarlo con el portugués de Brasil. Los objetivos fueron traducir y adaptar el Trait y el State Food Craving Questionnaire (FCQ-T y FCQ-S) al portugués de Brasil y evaluar las propiedades psicométricas de estas versiones. El FCQ-T $y$ el FCQ-S fueron traducidos y adaptados al portugués de Brasil y se administraron a estudiantes en la Universidad Federal de São Paulo. Se examinaron los modelos originales en ambos cuestionarios, considerando diferentes estimadores (de frecuencia y bayesianos). La bondad de ajuste que subyace en los items de ambas escalas se evaluó mediante los siguientes índices de ajuste: $\chi^{2}$, $W R M R$, indice de ajuste comparativo, el indice de Tucker-Lewis y la RMSEA. Los resultados contaron con los datos de 314 participantes que fueron incluidos en los análisis. Se obtuvieron escasos indices de ajuste en ambos cuestionarios originales, independientemente del estimador usado y modelo estructural original. De este modo, tres expertos en desórdenes alimenticios revisaron el contenido de los instrumentos y seleccionaron los items que fueron considerados, con el fin de evaluar los aspectos fundamentales del constructo "craving". Los modelos nuevos y reducidos (cuestionarios) generaron indices de ajuste positivos. Nuestras versiones abreviadas del FCQ-S y FCQ-T divergían considerablemente del marco conceptual respecto a los cuestionarios originales. Basado en los resultados de este estudio, proponemos una posible alternativa, por ejemplo, evaluar el craving for food como un constructo unidimensional.

Ansia; Trastorno por Atracón; Obesidad; Cuestionarios
Submitted on 21/Aug/2017

Final version resubmitted on 18/Jan/2018

Approved on 23/Feb/2018 